\title{
Antioxidant, Thrombolytic, Antimicrobial and Cytotoxic Activities of Flavonoids Isolated from the Root Bark of Pongamia pinnata
}

\author{
Seagufta Afrin ${ }^{1}$, Md. Abdul Muhit ${ }^{2}$, Md. Hossain Sohrab ${ }^{3}$, \\ Choudhury Mahmood Hasan ${ }^{1}$ and Monira Ahsan ${ }^{1}$
}

\author{
${ }^{1}$ Department of Pharmaceutical Chemistry, Faculty of Pharmacy, University of Dhaka \\ Dhaka-1000, Bangladesh \\ ${ }^{2}$ Department of Clinical Pharmacy and Pharmacology, Faculty of Pharmacy, University of Dhaka \\ Dhaka-1000, Bangladesh \\ ${ }^{3}$ Pharmaceutical Sciences Research Division, BCSIR Laboratories, Dr. Quadrat-I-Khuda Road \\ Dhanmondi, Dhaka-1205, Bangladesh
}

(Received: May 30, 2019; Accepted: February 24, 2020; Published: March 4, 2020)

\begin{abstract}
The crude methanolic extract of the root bark of Pongamia pinnata was taken into consideration to isolate secondary metabolites. A total six known natural compounds were separated and purified by various chromatographic techniques and five isolates were identified as flavonoid derivatives such as pongachromene (1), kanugin (2), karanjin (3), demethoxykanugin (4), dimethoxypongapine (5) and the other is a triterpenoid (6). The pure compounds as well as petroleum ether, dichloromethane and ethyl acetate soluble fractions of crude methanolic extract were evaluated for bioactivities using established methods. In vitro antioxidant activity was studied by DPPH radical scavenging method using butylated hydroxyl anisole as standard. Among the pure compounds, kanugin and pongachromene showed significant antioxidant activity with the $\mathrm{IC}_{50}$ values of $27.20 \pm 0.39 \mu \mathrm{g} / \mathrm{mL}$ and $43.53 \pm 0.63$ $\mu \mathrm{g} / \mathrm{ml}$, respectively as compared to the standard $(23.87 \pm 0.09 \mu \mathrm{g} / \mathrm{ml})$, whereas karanjin, demethoxykanugin and dimethoxypongapine demonstrated moderate antioxidant activity. Mild thrombolytic activity was observed by different fractions with clot lysis ranging from 18.49 to $29.35 \%$ as compared to standard streptokinase (79.12\%). The different solvent fractions and pure isolates showed very mild antimicrobial activity with zone of inhibition of 7.5 $10.0 \mathrm{~mm}$ against the tested microorganisms using azithromycin and ketoconazole as standards. In the brine shrimp lethality bioassay, the dichloromethane, ethyl acetate, and methanol soluble fractions revealed significant lethality with $\mathrm{LC}_{50}$ values of $0.67 \pm 0.05,0.61 \pm 0.13$ and $0.56 \pm 0.10 \mu \mathrm{g} / \mathrm{ml}$, respectively as compared to standard tamoxifen ( $\mathrm{LC}_{50}$ value $0.34 \pm 0.09 \mu \mathrm{g} / \mathrm{ml}$ ).
\end{abstract}

Key words: Pongamia pinnata, antioxidant, thrombolytic, pongachromene, kanugin, karanjin, demethoxykanugin and dimethoxypongapine.

\section{INTRODUCTION}

Pongamia pinnata (L.) Pierre (Fam: Fabaceae) locally known as karanja, is a medium sized evergreen tree found in gardens and road side all over Bangladesh as well as in India, China and South-East Asia. ${ }^{1}$ The plant has been recognized by various traditional and complementary medicine system for the treatment of human diseases for a long time. ${ }^{2}$ Meticulous review on this plant claimed that various

Correspondence to: Seagufta Afrin

E-mail: afrins1112@gmail.com

Phone: +8801739277376

Dhaka Univ. J. Pharm. Sci. 19(1): 1-8, 2020 (June)

DOI: https://doi.org/10.3329/dujps.v19i1.47812 parts of the plant have been used for the treatment of wide range of ailments, including antihyperglycemic, antilipidperoxidative, antifungal, antibacterial, antiinflammatory and antinociceptive activities. Moreover, the plant possesses protective effect against nephrotoxicity, antihyperammonemic effect, ulceroprotective and antiviral activity. ${ }^{3}$ Along with medicinal values, the plant has been used for producing biofuels, and has a potential role on agricultural systems. ${ }^{4}$

Previous phytochemical investigations reported abundant prenylated furano- and pyranoflavonoids 
and chalcones. ${ }^{5}$ In addition, terpenes, steroids, and fatty acids were isolated from different parts of the plant. The root bark contains a large number of flavones, flavanones, chalcones, $\beta$-diketone, $\beta$ hydroxychalcone, ponganones, karanjin, ovalitin $\mathrm{B}$, dihydromilletenone methyl ether, dimethoxyflavone, ovalifolin and furanoflavone. ${ }^{6}$ Pongapinone A, a hydroxychalcone derivatives was found in bark that has shown significant result in the treatment of autoimmune and inflammatory diseases. Flowers contain kaempferol and seeds contain a bitter fatty oil, karanjin, pongamol, glabrin, pongapine and also traces of essential oils. ${ }^{7}$

The present study reports the isolation of a total six compounds among which five flavonoids (1-5) and a triterpene lupeol (6) from root bark of the plant and the evaluation of antioxidant, thrombolytic, cytotoxic, and antimicrobial activities of different fractions of the crude extracts as well as the isolated pure compounds.

\section{MATERIALS AND METHODS}

General experimental procedure. ${ }^{1} \mathrm{H}$ NMR (400 MHz), ${ }^{13} \mathrm{C}$ NMR (100 MHz) and 2D NMR spectra were recorded on a Bruker Avance $400 \mathrm{MHz}$ Ultrashield NMR Spectrophotometer equipped with broadband and selective inverse probes. Chemical shifts are presented in $\delta$ (ppm) using tetramethylsilane (TMS) as internal standard and coupling constants $(J)$ are expressed in hertz. Buchii rotary evaporator was used to concentrate the different soluble extracts. Vacuum liquid chromatography (VLC) column was dri-packed with Kiselgel $60 \mathrm{H}$ under suction. Gel permeation chromatography was run over using lipophilic Sephadex LH-20. Analytical and preparative thin layer chromatography (TLC and PTLC) were performed on glass plates coated with silica gel (Kiselgel $60 \mathrm{PF}_{254}$ ). The TLC spots were visualized under UV light at 254 and $366 \mathrm{~nm}$ and also by spraying with dil. $\mathrm{H}_{2} \mathrm{SO}_{4}$ followed by heating. All the solvents were distilled before use.

Plant material. The root bark of the plant was collected from low land of Jhalokathi district,
Bangladesh in June, 2015. The plant material was identified by Mr. Sardar Nasir Uddin, National Herbarium, Dhaka and a voucher specimen was produced for future references under the Accession No. DACB- 43574.

Extraction and isolation. The air dried and coarsely powdered dried root barks $(1.0 \mathrm{~kg})$ were soaked in methanol $(3.5 \mathrm{~L})$ for 15 days at room temperature with occasional stirring. The soaked methanolic extracts were filtered first with cotton plug and then using Whatman filter paper No. 1. The solvents were evaporated into a rotary evaporator at $40^{\circ} \mathrm{C}$ to yield a viscous mass of crude extract $(20$ gm). An aliquot of the crude methanolic extract was subjected to vacuum liquid chromatography (VLC) using silica gel $60 \mathrm{H}$ and fractionated using petroleum ether, petroleum ether-dichloromethane, dichloromethane-ethyl acetate, ethyl acetate, ethyl acetate-methanol and finally methanol in increasing order of polarities. A total of 40 fractions were collected and pooled for TLC analysis.

Visualizing the TLC pattern of VLC fractions, the $80 \%$ dichloromethane in petroleum ether (VLC fraction no. 18) fraction was subjected to gel permeation chromatography using Sephadex (LH-20) as stationary phase and different amount of petroleum ether-chloroform as mobile phase. Compound 1 was obtained as off white crystals (8.0 $\mathrm{mg}$ ) from the Sephadex column fraction eluted with $10 \%$ petroleum ether in chloroform and was purified by PTLC (5\% ethyl acetate in toluene) and the $\mathrm{R}_{\mathrm{f}}$ value was found 0.49 (10\% ethyl acetate in toluene). The VLC fraction no. 25, eluted with $8 \%$ ethyl acetate in dichloromethane was also subjected to gel permeation chromatography and PTLC (8\% ethyl acetate in toluene) to afford compound $\mathbf{2}$ (off white gum, $6.5 \mathrm{mg}$ ), 4 (pale yellow crystals, $5.0 \mathrm{mg}$ ) and 5 (pale yellow crystals, $5.0 \mathrm{mg}$ ), with $\mathrm{R}_{\mathrm{f}}$ values 0.26 , 0.35 , and 0.36 respectively in $10 \%$ ethyl acetate in toluene.

VLC fraction no. 26 (10\% ethyl acetate in dichloromethane) followed by fractionation with Sephadex column and then PTLC using 10\% ethyl acetate in toluen gave compound $\mathbf{3}$ (off white 
crystals, $7.0 \mathrm{mg}$ ); $\mathrm{R}_{\mathrm{f}}$ value 0.45 in $10 \%$ ethyl acetate in toluene. Concentrated VLC fraction no. 27 (12\% ethyl acetate in dichloromethane) provided white needle shaped crystals of compound $6(15.0 \mathrm{mg})$ with $\mathrm{R}_{\mathrm{f}}$ value 0.52 in $10 \%$ ethyl acetate in toluene.

\section{Properties of Compounds (1-6)}

Pongachromene (1). Off white crystals; ${ }^{1} \mathrm{H}$ NMR $\left(400 \mathrm{MHz}, \mathrm{CDCl}_{3}\right): \delta 1.49\left(6 \mathrm{H}, \mathrm{s}, \mathrm{Me}-2^{\prime \prime}\right), 3.86(3 \mathrm{H}$, s, OMe), $5.71\left(1 \mathrm{H}, \mathrm{d}, J=10.0 \mathrm{~Hz}, \mathrm{H}-3^{\prime \prime}\right), 6.06(2 \mathrm{H}, \mathrm{s}$, $\left.\mathrm{OCH}_{2} \mathrm{O}\right), 6.82(1 \mathrm{H}, \mathrm{d}, J=8.7 \mathrm{~Hz}, \mathrm{H}-6), 6.85(1 \mathrm{H}, \mathrm{d}$, $\left.J=10 \mathrm{~Hz}, \mathrm{H}-4^{\prime \prime}\right), 6.94$ (1H, d, $\left.J=8.3 \mathrm{~Hz}, \mathrm{H}-5^{\prime}\right), 7.59$ $\left(1 \mathrm{H}, \mathrm{d}, J=1.5 \mathrm{~Hz}, \mathrm{H}-2^{\prime}\right), 7.67(1 \mathrm{H}, \mathrm{dd}, J=8.3,1.5$ Hz, H-6'), 7.99 (1H, d, $J=8.7 \mathrm{~Hz}, \mathrm{H}-5) ;{ }^{13} \mathrm{C}$ NMR $\left(100 \mathrm{MHz}, \mathrm{CDCl}_{3}\right): \delta 174.5$ (C-4), 165.0 (C-7), 157.3 (C-2), 154.3 (C-5), 151.2 (C-9), 149.4 (C-4'), 147.9 (C-3'), 126.5 (C-3"), 122.5 (C-1' and 6'), 115.9 (C4"), 109.3 (C-5'), 107.7 (C-2'), 107.6 (C-10), 103.4 (C-8), $101.6\left(\mathrm{OCH}_{2} \mathrm{O}\right), 99.9$ (C-6), $77.3\left(\mathrm{C}-2^{\prime \prime}\right), 60.7$ $\left(\mathrm{OCH}_{3}\right), 28.8$ (Me-2"), 27.5 (Me-2").

Kanugin (2). Off white gum; ${ }^{1} \mathrm{H}$ NMR (400 $\left.\mathrm{MHz}, \mathrm{CDCl}_{3}\right): \delta 3.87(3 \mathrm{H}, \mathrm{s}, \mathrm{OMe}-7), 3.91(3 \mathrm{H}, \mathrm{s}$, OMe-3), 3.97 (3H, s, OMe-5'), $6.07\left(2 \mathrm{H}, \mathrm{s}, \mathrm{OCH}_{2} \mathrm{O}\right)$, $6.88(1 \mathrm{H}, \mathrm{d}, J=2.1 \mathrm{~Hz}, \mathrm{H}-8), 6.96(1 \mathrm{H}, \mathrm{dd}, J=8.9$, $2.1 \mathrm{~Hz}, \mathrm{H}-6), 7.31\left(1 \mathrm{H}, \mathrm{d}, J=1.2 \mathrm{~Hz}, \mathrm{H}-6{ }^{\prime}\right), 7.43$ $(1 \mathrm{H}$, br. s, H-2'), $8.14(1 \mathrm{H}, \mathrm{d}, J=8.9 \mathrm{~Hz}, \mathrm{H}-5)$.

Karanjin (3). Off white crystals; ${ }^{1} \mathrm{H}$ NMR (400 $\left.\mathrm{MHz}, \mathrm{CDCl}_{3}\right): \delta 3.95$ (3H, s, OMe-3), $7.21(1 \mathrm{H}, \mathrm{d}, J$ $\left.=2.4 \mathrm{~Hz}, \mathrm{H}-3^{\prime \prime}\right), 7.57$ (3H, m, H-3'-5'), $7.59(1 \mathrm{H}, \mathrm{d}, J$ $=8.8 \mathrm{~Hz}, \mathrm{H}-6), 7.78\left(1 \mathrm{H}, \mathrm{d}, J=2.4 \mathrm{~Hz}, \mathrm{H}-2^{\prime \prime}\right), 8.17$ $(1 \mathrm{H}, \mathrm{dd}, J=8.4,2.0 \mathrm{~Hz}, \mathrm{H}-2 '), 8.17(1 \mathrm{H}$, overlapped, H-6'), 8.22 (1H, d, $J=8.8 \mathrm{~Hz}, \mathrm{H}-5)$.

Demethoxykanugin (4). Pale yellow crystals; ${ }^{1} \mathrm{H}$ NMR (400 MHz, $\left.\mathrm{CDCl}_{3}\right): \delta 3.86(3 \mathrm{H}, \mathrm{s}, \mathrm{OMe}-3)$, $3.90(3 \mathrm{H}, \mathrm{s}, \mathrm{OMe}-7), 6.06\left(2 \mathrm{H}, \mathrm{s}, \mathrm{OCH}_{2} \mathrm{O}\right), 6.89(1 \mathrm{H}$, $\left.\mathrm{d}, J=1.5 \mathrm{~Hz}, \mathrm{H}-8), 6.94(1 \mathrm{H}, \mathrm{d}, J=8.2 \mathrm{~Hz}, \mathrm{H}-5)^{\prime}\right)$, $6.96(1 \mathrm{H}, \mathrm{dd}, J=8.9,1.5 \mathrm{~Hz}, \mathrm{H}-6), 7.61(1 \mathrm{H}$, br. s, H-2'), $7.69(1 \mathrm{H}$, br. d, $J=8.2 \mathrm{~Hz}, \mathrm{H}-6$ '), $8.14(1 \mathrm{H}, \mathrm{d}$, $J=8.9 \mathrm{~Hz}, \mathrm{H}-5)$.

Dimethoxypongapine (5). Pale yellow crystals; ${ }^{1} \mathrm{H}$ NMR (400 MHz, $\left.\mathrm{CDCl}_{3}\right): \delta 3.91$ (3H, s, OMe-3), $3.99\left(3 \mathrm{H}, \mathrm{s}, \mathrm{OMe}-5^{\prime}\right), 6.09\left(2 \mathrm{H}, \mathrm{s}, \mathrm{OCH}_{2} \mathrm{O}\right), 7.16(1 \mathrm{H}$, br. s, H-2"), $7.36(1 \mathrm{H}$, br. s, H-6'), $7.52(1 \mathrm{H}$, br. s, H2'), $7.54(1 \mathrm{H}, \mathrm{d}, J=8.7 \mathrm{~Hz}, \mathrm{H}-6), 7.76(1 \mathrm{H}$, br. s, H$\left.3^{\prime \prime}\right), 8.17(1 \mathrm{H}, \mathrm{d}, J=8.7 \mathrm{~Hz}, \mathrm{H}-5)$.
Lupeol (6). White needle shaped crystals; ${ }^{1} \mathrm{H}$ NMR (400 MHz, $\left.\mathrm{CDCl}_{3}\right): \delta \quad 0.78,0.82,0.85,0.96$, 0.99, 1.05 (each 3H, s), 1.70 (3H, s, H-30), $3.21(1 \mathrm{H}$, dd, $J=6.0,2.0 \mathrm{~Hz}, \mathrm{H}-3), 4.59$ (1H, br. s, $\left.\mathrm{H}_{\mathrm{a}}-29\right), 4.71$ $\left(1 \mathrm{H}\right.$, br. s, $\left.\mathrm{H}_{\mathrm{b}}-29\right)$.

Antioxidant activity. Antioxidant activity of the test sample was measured using DPPH free radical scavenging assay which was designed by Feresin et $a l .{ }^{8}$ Here, the ability of a test sample in a reduction reaction with the free radical 1,1-diphenyl-2picrylhydrazyl (DPPH) in an alcoholic solution was measured. Upon addition with the test sample, the decolorization of the free radical solution is occurred that has been observed in the change of absorbance in a spectrophotometer. Butylated hydroxyl anisole (BHA), the reference standard was used as a known hydrogen donor. Inhibition of free radical DPPH in percent (I\%) was calculated using the following equation:

$$
\mathrm{I} \%=100\left(\mathrm{~A}_{\text {control }}-\mathrm{A}_{\text {sample }}\right) / \mathrm{A}_{\text {control }}
$$

where, $\mathrm{A}_{\text {control }}$ was the absorbance of DPPH solution without test samples and $\mathrm{A}_{\text {sample }}$ was the absorbance of the sample with test compounds. The concentration required for $50 \%$ inhibition $\left(\mathrm{IC}_{50}\right)$ was calculated from percentage inhibition vs concentration plot drawn in a Microsoft Excel Spread Sheet. Generally the lower the $\mathrm{IC}_{50}$ value, the higher the antioxidant capacity.

Thrombolytic activity. In vitro antithrombotic activity of the crude extracts of $P$. pinnata were performed by an established protocol reported by Prasad et al. ${ }^{9}$ using Streptokinase $(100 \mu \mathrm{L})$ as positive control. Venous blood was withdrawn from healthy human volunteers $(n=10)$ and then transferred in previously weighed sterile eppendorf tubes and incubated at $37^{\circ} \mathrm{C}$ for 45 minutes for clotting. After incubation, the fluid released was removed and tubes were weighed again to observe the difference in weight after clot disruption. $500 \mu \mathrm{L}$ of plant extracts/samples with a concentration of $5 \mathrm{mg} / \mathrm{mL}$ was added to the eppendorf tubes. $100 \mu \mathrm{L}$ of Streptokinase and distilled water each were separately added to the control tubes. All the tubes were incubated at $37^{\circ} \mathrm{C}$ for 90 minutes and observed 
for clot lysis. The fluid left was then carefully removed and the tubes were weighed again. The difference in weight before and after clot lysis were expressed as \% clot lysis.

Antimicrobial activity. Antimicrobial activity was screened using disc diffusion technique as described previously. ${ }^{10}$ Two gram positive bacteria and two gram negative bacteria were cultured in separate petridish with nutrient agar medium. Standard Streptomycin $(30 \mu \mathrm{g} / \mathrm{disc})$ discs were used as reference antibiotic. $20 \mu \mathrm{L}$ solution from 20 $\mathrm{mg} / \mathrm{mL}$ of the each solvent crude extracts and 5 $\mathrm{mg} / \mathrm{mL}$ of the pure isolated compounds were added to the blank disc to achieve the concentration of 400 $\mu \mathrm{g} / \mathrm{disc}$ for extracts and $100 \mu \mathrm{g} /$ disc for pure compounds, respectively. The sample discs were placed slightly deep into Petri dishes with the previously inoculated test organism. The plates were incubated in $37^{\circ} \mathrm{C}$ incubator placing upside down whole night. Clear zone of inhibition was calculated with a slide calipers to evaluate the antimicrobial activity.

Brine shrimp lethality assay. The brine shrimp lethality assay, a simple and robust technique has been widely used for the preliminary screening of crude drugs to evaluate their toxicity. Ten different concentrations of each test sample were applied against Artemia salina in a one-day in vitro assay to get a linear relationship. Artificial sea water was prepared by adding $\mathrm{NaCl}$ into distilled water which was described by Meyer et al. ${ }^{11}$ with slight modification. Tamoxifen, a known anticancer agent was used as positive control. The median lethal concentration $\left(\mathrm{LC}_{50}\right)$ of the test samples after 8 hours exposure were determined from a plot of $\%$ of the dead shrimps against the logarithm of the sample concentration.

\section{RESULTS AND DISCUSSION}

Compound 1 was obtained as off white needle shaped crystals. The ${ }^{1} \mathrm{H}$ NMR spectrum (400 MHz, $\mathrm{CDCl}_{3}$ ) showed two ortho-coupled aromatic proton, appeared as doublets at $\delta 7.99(\mathrm{~J}=8.7 \mathrm{~Hz})$ and 6.82 $(J=8.7 \mathrm{~Hz})$ and could be assigned to $\mathrm{H}-5$ and H-6, respectively. Three aromatic proton muliplets were observed at $\delta 7.59(\mathrm{dd}, J=1.5 \mathrm{~Hz}), 6.94(\mathrm{~d}, J=8.3$ $\mathrm{Hz})$ and $7.67(\mathrm{dd}, J=8.3 \mathrm{~Hz}, 1.5 \mathrm{~Hz})$ assignable to H-2', H-5' and H-6', respectively of ring $\mathrm{B}$ of the flavonoid skeleton. Two olefinic protons at $\delta 5.71$ and 6.85 with coupling constant of $10.0 \mathrm{~Hz}$ together with two methyl groups at $\delta 1.49(6 \mathrm{H}, \mathrm{s})$, suggested the presence of 2 ", 2 "'-dimethyl chromene ring. A methylene dioxy group at $\delta 6.06(2 \mathrm{H}, \mathrm{s})$ was associated with $\mathrm{H}-3^{\prime}$ and $\mathrm{H}^{-} 4^{\prime}$ position. A singlet signal at $\delta 3.86$ integrating three protons was assigned as C-3 methoxy group. The ${ }^{13} \mathrm{C}$ NMR revealed 21 carbons including a carbonyl carbon at $\delta$ 174.5 (C-4), a methylene-dioxy carbon at $\delta 101.6$, a methoxy carbon at $\delta 60.7$ and two methyl carbons at $\delta 27.5$ and 28.8. The COSY spectrum revealed the couplings between the protons $\mathrm{H}-5 / \mathrm{H}-6, \mathrm{H}-5^{\prime} / \mathrm{H}-6^{\prime}$ and $\mathrm{H}-3^{\prime \prime} / \mathrm{H}-4^{\prime \prime}$.On the basis of these data, the structure of compound 1 (Figure 1) was elucidated as 3-methoxy-2", 2"-dimethyl-3',4'-methylenedioxypyranoflavone or pongachromene and was confirmed by comparing its NMR data in published literature. ${ }^{12}$

Compound 2, isolated as off white gummy mass displayed three ABX-type aromatic protons in its ${ }^{1} \mathrm{H}$ NMR spectrum, at $\delta 8.14(1 \mathrm{H}, \mathrm{d}, J=8.9 \mathrm{~Hz}), 6.96$ $(1 \mathrm{H}, \mathrm{dd}, J=8.9,2.1 \mathrm{~Hz})$ and $6.88(1 \mathrm{H}, \mathrm{d}, J=2.1 \mathrm{~Hz})$ which were assigned to $\mathrm{H}-5, \mathrm{H}-6$ and $\mathrm{H}-8$ of ring $\mathrm{A}$ of the flavonoid nucleus. Two meta-coupled aromatic protons were observed at $\delta 7.43(1 \mathrm{H}$, br. s) and 7.31 $\left(1 \mathrm{H}, \mathrm{d}, J=1.2 \mathrm{~Hz}\right.$ ) which can be assigned to $\mathrm{H}-2^{\prime}$ and $\mathrm{H}-6^{\prime}$, respectively. A methylenedioxy group at $\delta$ $6.07(2 \mathrm{H}, \mathrm{s})$ was associated with $\mathrm{H}^{-} 3^{\prime}$ and $\mathrm{H}-4^{\prime}$. Three methoxy group protons at $\delta 3.91,3.87$ and 3.97 were attached to $3,7,5^{\prime}$-carbons, respectively. The above data suggested the structure of compound $\mathbf{2}$ as 3,7,5'-trimethoxy-3'4'methylene-dioxyflavone (kanugin) which was found to be similar with the reported values for kanugin. ${ }^{13}$

Compound 3, obtained as off white crystals showed two ortho-coupled aromatic protons at $\delta 8.22$ $(1 \mathrm{H}, \mathrm{d}, J=8.8 \mathrm{~Hz})$ and $7.59(1 \mathrm{H}, \mathrm{dd}, J=8.9 \mathrm{~Hz})$ in the ${ }^{1} \mathrm{H}$ NMR spectrum assignable to $\mathrm{H}-5$ and $\mathrm{H}-6$, respectively. A characteristic furan ring was observed due to proton signals at $\delta 7.78(1 \mathrm{H}, \mathrm{d}, J=2.4 \mathrm{~Hz}, \mathrm{H}-$ 
$\left.2^{\prime \prime}\right)$ and $7.21\left(1 \mathrm{H}, \mathrm{d}, J=2.4 \mathrm{~Hz}, \mathrm{H}-3^{\prime \prime}\right)$ which could be attached to C-7 and C-8 of ring A of the flavonoid. Five aromatic proton multiplets from $\delta 7.57$ to 8.17 indicated the presence of a mono-substituted benzene ring (ring-B). C-3 methoxy group protons were appeared at $\delta 3.95$ integrating three protons. On the basis of above NMR data, the structure of compound 3 was established as 3-methoxy-2-phenyl-4Hfuro[2",3"-h] flavone, also known as karanjin, which has previously been isolated from this plant. ${ }^{14}$

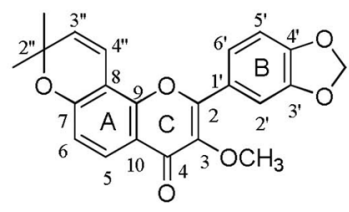

Pongachromene (1)

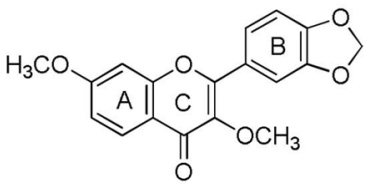

Demethoxykanugin (4)

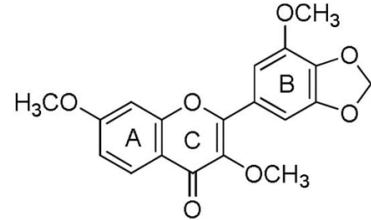

Kanugin (2)

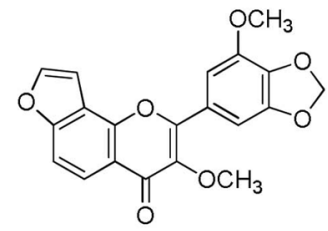

Dimethoxypongapine (5)

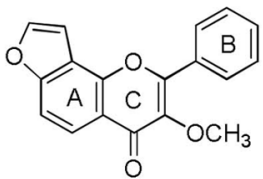

Karanjin (3)

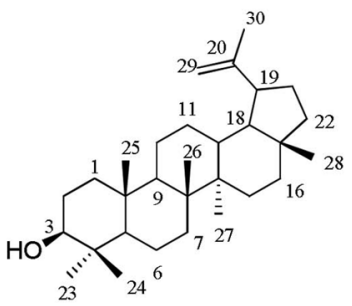

Lupeol (6)

Figure 1. Compounds 1-6 isolated from $P$. pinnata

Compound 4, isolated as pale yellow crystals, revealed in its ${ }^{1} \mathrm{H}$ NMR spectrum, six aromatic protons at $\delta 8.14(1 \mathrm{H}, \mathrm{d}, J=8.9 \mathrm{~Hz}, \mathrm{H}-5), 6.96(1 \mathrm{H}$, dd, $J=8.9,1.5 \mathrm{~Hz}, \mathrm{H}-6), 6.89(1 \mathrm{H}, \mathrm{d}, J=1.5 \mathrm{~Hz}, \mathrm{H}-$ 8), $7.61(1 \mathrm{H}$, br. s, H-2'), $6.94(1 \mathrm{H}, \mathrm{d}, J=8.2 \mathrm{~Hz}, \mathrm{H}-$ $\left.5^{\prime}\right)$ and $7.69\left(1 \mathrm{H}\right.$, br. d, $\left.J=8.2 \mathrm{~Hz}, \mathrm{H}-6^{\prime}\right)$ and suggested the presence of two aromatic ring with $\mathrm{ABX}$ system (ring-A and ring-B). A two proton singlet at $\delta 6.06$ indicated a methylenedioxy group at position $\mathrm{H}-3^{\prime}$ and $\mathrm{H}-4$ '. Two three proton singlets at $\delta$ 3.86 and 3.90 could be assigned to C-3 and C-7 methoxy groups, respectively. On this basis, compound 4 was established as 3,7-dimethoxy-3'4'methylenedioxyflavones and its spectral data were matched with those reported for demethoxykanugin. ${ }^{15}$

Compound 5, showed two ortho-coupled aromatic proton doublets at $\delta 8.17(1 \mathrm{H}, \mathrm{d}, J=8.7 \mathrm{~Hz})$ and $7.54(1 \mathrm{H}, \mathrm{d}, J=8.7 \mathrm{~Hz})$ in the ${ }^{1} \mathrm{H}$ NMR spectrum, and were assigned as $\mathrm{H}-5$ and H-6 respectively. Two proton doublets appeared at $\delta 7.16$ $(1 \mathrm{H}$, br. s) and $7.76(1 \mathrm{H}$, br. s), are the characteristic signal of $\mathrm{H}-2$ " and $\mathrm{H}-3$ " of a furan ring. The appearance of two protons at $\delta 7.36\left(1 \mathrm{H}\right.$, br. s, H-6 $\left.6^{\prime}\right)$ and $7.52(1 \mathrm{H}$, br. s, H-2'), indicated a tetra substituted ring B. A methylenedioxy group at position $\mathrm{H}-3$ ' and H-4' was evident from a signal at $\delta 6.09$ that integrated for two protons. Two methoxyl proton signals at $\delta 3.91(3 \mathrm{H}, \mathrm{s})$ and $3.99(3 \mathrm{H}, \mathrm{s})$ were placed at $\mathrm{C}-3$ and $\mathrm{C}-5$ ' respectively. Thus, the structure of compound 5 was established as 3,5'-dimethoxy-4Hfuro[2",3"-h]-3', 4'-methylenedioxyflavone (dimethoxypongapine). Its identity was further confirmed by comparing the above data with published values. ${ }^{16}$

The ${ }^{1} \mathrm{H}$ NMR spectrum of compound $\mathbf{6}$ showed the presence of characteristic two exomethylene protons at $\delta 4.71,4.59$ and a vinylic methyl proton at 1.70 together with an oxymethine proton at $\delta 3.21$ and six methyls at $\delta 0.78,0.82,0.85,0.96,0.99,1.05$ (each $3 \mathrm{H}, \mathrm{s})$. This structural features were compared with the reported values for lupeol and found to be similar with it. ${ }^{17}$

Antioxidant activity. Free radicals, generated by exogenous or endogenous causes in human, may damage the cell and tissues. Reactive oxygen or 
nitrogenous species can be neutralized by our body through superoxide dismutase, glutathione stransferase, and catalase enzymes. Other than this, plants especially edible plant species can play a vital role to eliminate this free radicals by various reactions because they contain polyphenolic compounds such as tocopherols, flavonoids, phenolics, tannins etc. ${ }^{18}$ As the investigated plant possesses a variety of flavonoids, different organic fractions of $P$. pinnata and isolated pure compounds were subjected to evaluation of antioxidant activity on the stable radical 1,1-diphenyl-2-picrylhydrazyl (DPPH). The $\mathrm{IC}_{50}$ value of BHA was used as reference for which the activity was found to be $23.87 \pm 0.09 \mu \mathrm{g} / \mathrm{mL}$. Among the flavonoids that are isolated in this study kanugin (2) and pongachromene (1) showed excellent antioxidant activity with the lowest $\mathrm{IC}_{50}$ value $27.20 \pm 0.39 \mu \mathrm{g} / \mathrm{mL}$ and $43.53 \pm 0.63$ $\mu \mathrm{g} / \mathrm{mL}$, respectively. There is a positive correlation with flavonoid contents and antioxidant activity ${ }^{19}$ which is found in this study too. During the evaluation of methanol, ethyl acetate and dichloromethane soluble fractions of the plant showed moderate inhibitory concentration with $\mathrm{IC}_{50}$ values of $127.57 \pm 0.68,129.00 \pm 0.22$ and $376.43 \pm 0.65$ $\mu \mathrm{g} / \mathrm{mL}$, respectively (Table 1 ).

Table 1. DPPH free radical scavenging activity of different fractions and isolated compounds of $P$. pinnata.

\begin{tabular}{lc}
\hline Sample & $\mathrm{IC}_{50}$ value $(\mu \mathrm{g} / \mathrm{ml})$ \\
\hline BHA (positive control) & $23.87 \pm 0.09$ \\
PESF & $812.62 \pm 0.36$ \\
DCMSF & $376.43 \pm 0.65$ \\
EASF & $129.00 \pm 0.22$ \\
MESF & $127.57 \pm 0.68$ \\
Pongachromene (1) & $43.53 \pm 0.63$ \\
Kanugin (2) & $27.20 \pm 0.39$ \\
Karanjin (3) & $200.81 \pm 0.67$ \\
Demethoxykanugin $(\mathbf{4})$ & $176.09 \pm 0.43$ \\
Dimethoxypongapine $(\mathbf{5})$ & $213.17 \pm 0.46$ \\
\hline
\end{tabular}

Values are represented as mean \pm SEM $(n=3)$, PESF: Petroleum ether soluble fraction, DCMSF: Dichloromethane soluble fraction, EASF: Ethyl acetate soluble fraction, MESF: Methanol soluble fraction.
Thrombolytic activity. Thrombolytic or fibrinolytic solvent are widely used for the treatment of cerebral venous sinus thrombosis (CVST) and myocardial infarction. Different kinds of drugs such as tissue plasminogen activator (t-PA), Streptokinase, Urokinase etc. are used but they possess serious bleeding complication along with high cost treatment. ${ }^{20}$ Plants may possess secondary metabolites such as tannins, alkaloids, saponins that have shown thrombolytic properties. ${ }^{21}$ Few Bangladeshi plant extracts have shown moderate to strong thrombolytic activity too. ${ }^{22}$ The extract of root bark of $P$. pinnata was investigated for thrombolytic properties and found moderate clot lysis activity. Among all the fractions, the ethyl acetate fraction showed highest clot lysis activity $(29.35 \pm 0.07 \%)$, whereas standard streptokinase at $37^{\circ} \mathrm{C}$ showed $79.12 \pm 0.10 \%$ lysis of the clot as compared to distilled water showing a negligible clot lysis $(3.76 \pm 0.15 \%)$ (Table 2).

Table 2. Thrombolytic activity of different soluble fractions of P. pinnata.

\begin{tabular}{lc}
\hline Sample & \% clot lysis \\
\hline Saline water & $3.76 \pm 0.15$ \\
PESF & $19.63 \pm 0.11$ \\
DCMSF & $18.49 \pm 0.08$ \\
EASF & $29.35 \pm 0.07$ \\
MESF & $26.48 \pm 0.48$ \\
Streptokinase & $79.12 \pm 0.10$ \\
\hline
\end{tabular}

Values are represented as mean \pm SEM $(n=3)$, PESF: Petroleum ether soluble fraction, DCMSF: Dichloromethane soluble fraction, EASF: Ethyl acetate soluble fraction, MESF: Methanol soluble fraction.

Antimicrobial activity. Antimicrobial activity of different fractions and isolated compounds of $P$. pinnata were tested against two gram positive (Bacillus megaterium, Staphylococcus aureas) and two gram negative (Escherichia coli, Salmonella typhi) bacterial species along with one fungus (Aspergillus niger). All of the fractions of $P$. pinnata and pure compounds showed poor antimicrobial activity with a zone of inhibition in the range of 7.5$10.0 \mathrm{~mm}$ against all microbes (data are not shown here) where azithromycin and ketoconazole were 
used as standards. The antimicrobial activity of pure compounds could not be observed in our experiment.

Brine shrimp lethality bioassay. The over consumption of medicinal plants can eventually lead to excessive accumulation of toxic metabolites in the body, which may cause various toxicities. ${ }^{23}$ Brine shrimp lethality bioassay is a rapid and robust technique to know the cytotoxicity of any compounds. In this investigation, the median lethal concentration $\left(\mathrm{LC}_{50}\right)$ of the test samples after 8 hours were obtained by a plot of percentage of the shrimps killed against the logarithm of the sample concentration (toxicant concentration). DCMSF, EASF and MESF showed significant cytotoxicity in brine shrimp with $\mathrm{LC}_{50}$ values as $0.67 \pm 0.05 \mu \mathrm{g} / \mathrm{mL}$, $0.61 \pm 0.13 \mu \mathrm{g} / \mathrm{mL}$ and $0.56 \pm 0.10 \mu \mathrm{g} / \mathrm{mL}$, respectively, whereas the standard tamoxifen showed $\mathrm{LC}_{50}$ value $0.34 \pm 0.09 \mu \mathrm{g} / \mathrm{mL}$. Previous study suggested that aqueous extract of $P$. pinnata showed toxicity against Daphnia which is in accordance with our finding. ${ }^{24}$

Table 3. Brine shrimp lethality activity of different fractions of P. pinnata.

\begin{tabular}{lc}
\hline Sample & LC $_{50}$ value $(\mu \mathrm{g} / \mathrm{ml})$ \\
\hline PESF & $2.39 \pm 0.14$ \\
DCMSF & $0.67 \pm 0.05$ \\
EASF & $0.61 \pm 0.13$ \\
MESF & $0.56 \pm 0.10$ \\
Tamoxifen & $0.34 \pm 0.09$ \\
\hline
\end{tabular}

Values are represented as mean \pm SEM $(n=3)$. PESF: Petroleum ether soluble fraction, DCMSF: Dichloromethane soluble fraction, EASF: Ethyl acetate soluble fraction, MESF: Methanol soluble fraction.

\section{CONCLUSION}

The present study concluded that various soluble fractions of the root bark of $P$. pinnata have moderate to strong antioxidant, thrombolytic and brine shrimp cytotoxic activities. These bioactivities support the folk uses of $P$. pinnata in various diseases. The isolated pure compounds showed significant antioxidant activities. As $P$. pinnata is rich in flavonoid compounds this can be used as a potential source of antioxidant and cytotoxic agents in the development of new therapeutic agents.

\section{ACKNOWLEDGEMENTS}

We would like to thank to Bangladesh Council for Scientific Research Laboratory (BCSIR) for providing bacterial strains and carrying out NMR experiment. The authors would like to acknowledge the facilities provided by Northern University Bangladesh for thrombolytic activity and Bangladesh National Herbarium for identifying the plant.

\section{REFERENCES}

1. Ghani, A. 2003. Medicinal Plants of Bangladesh with Chemical Constituents and Uses. Asiatic Society of Bangladesh, $2^{\text {nd }}$ edition, pp. 354-355.

2. Ghumare, P., Jirekar, D. B., Farooqui, M. and Naikwade S. D. 2014. A review of Pongamia pinnata-an important medicinal. Curr. Res. Pharma. Sci. 4, 44-47.

3. Arote, S.R. and Yeole, P. G. 2010. Pongamia pinnata L: A comprehensive review. Int. J. Pharm Tech. Res. 2, 22832290

4. Naik, M., Meher, L.C., Naik, S.N. and Dasa, L.M. 2008. Production of biodiesel from high free fatty acid karanja (Pongamia pinnata) oil. Biomass Bioenergy. 32, 354-357.

5. Meera, B. and Kalidhar, S.B. 2004. Chemical components of Pongamia pinnata L. J. Ind. Chem. Soc. 81, 891-892.

6. Tanaka,T., Iinuma, M., Yuki, K., Fujii,Y. and Mizuno, M. 1992. Flavonoids in root bark of Pongamiapinnata. The Int. J. Plant Biochem. 31, 993-998.

7. Al Muqarrabun, L.M., Ahmat, N., Ruzaina, S.A., Ismail, N.H. and Sahidin I. 2013. Medicinal uses, phytochemistry and pharmacology of Pongamia pinnata (L.). $J$ Ethnopharmacol. 150, 395-420.

8. Feresin, G.E., Tapia, A., Gutierrez, R.A., Delporte, C., Backhouse, E.N. and Schmeda, H.G. 2002. Free radical scavengers, anti-inflammatory and analgesic activity of Acaenama gellanica. J. Pharm. Pharmacol. 54, 835-844.

9. Prasad, S., Kashyap, R.S., Deopujari, J.Y., Purohit, H.J., Taori, G.M. and Daginawala, H.F. 2007. BMC Comp. Alter. Med. 7, 36 .

10. Rashid, P. T., Ahmed, M., Rahaman, M.M. and Muhit, M.A. 2018. 14-Deoxyandrographolide isolated from Andrographis paniculata (Burm. f) Nees growing in Bangladesh and its antimicrobial properties. Dhaka Univ. J. Pharm. Sci. 17, 265267.

11. Meyer, B.N., Ferringni, N.R., Puam, J. E., Lacobsen, L. B., Nichols, D. E. and McLaughlin J. L. 1982. Brine shrimp: a convenient general bioassay for active constituents. Planta Med. 45, 31-32.

12. Mukerjee, S. K., Sarker, S.C. and Seshadri, T.R. 1969. The structure and synthesis of pongachromene, a new component of Pongamia glabra. Tetrahedron 25, 1063-1069. 
13. Rangaswami, S., Rao, J.V. and Seshadri, T.R. 1942. Kanugin, a crystalline component of the roots of Pongamia glabra. Proc. Indian Acad. Sci. (Math. Sci.) 16, 319.

14. Dhanmane, S.K. and Faisal, A.S. 2018. Isolation of karanjin from Pongamia pinnata and its identification by different analytical techniques. Kurdistan J. App. Res. Special issue, 156-160.

15. Mittal, O.P. and Seshadri, T.R. 1956. Demethoxykanugin: a new crystalline compound from Pongamia glabra. J. Chem. Soc. 2176-2178.

16. Carcache-Blanco, E.J., Kang, Y.H., Park, E.J., Su, B.N., Kardono, L.B.S., Riswan, S. and Kinghorn, A.D. 2003. Constituents of the Stem bark of Pongamia pinnata with the potential to induce quinone reductase. J. Nat. Prod. 66, 1197 1202.

17. Saleem, M. 2009. Lupeol, a novel anti-inflammatory and anti-cancer dietary triterpene. Cancer Lett. 285, 109-115.

18. Meena, H., Pandey, H.K., Pandey, P., Arya, M.C. and Ahmed, Z. 2012. Evaluation of antioxidant activity of two important memory enhancing medicinal plants Baccopa monnieri and Centella asiatica. Ind. J. Pharmacol. 44, 114-117.
19. Asem, N., Abdul Gapar, N.A., Abd Hapit, N.H. and Omar, E. A. 2019. Correlation between total phenolic and flavonoid contents with antioxidant activity of Malaysian stingless bee propolis extract. J. Apic. Res. 1-6.

20. Katzung, B.G. 2008. Basic and Clinical Pharmacology. McGraw-Hill Education (Asia), $10^{\text {th }}$ Edition, p. 545.

21. Ali, M. R., Kuri, S., Das, A. and Islam, M. A. 2013. Preliminary phytochemical screening and in vitro thrombolytic potential of the methanolic extract of Enhydra fluctuans Lour (leaves). Int. J. Pharmamedix India, 1, 270280.

22. Hussain, M.F., Islam, A., Bulbul, M.L., Moghal, M.M. and Hossain, M.S. 2014. In vitro thrombolytic potential of root extracts of four medicinal plants available in Bangladesh. Anc. Sci. Life. 33, 162-164.

23. Mirzaei, M. and Mirzaei, A. 2013. Comparison of the Artemia salina and Artemia uramiana bioassays for toxicity of four Iranian medicinal plants. Int. Res. J. Biol. Sci. 2, 4954.

24. Shirsat, R. and Aruna, R. 2015. In vitro cytotoxic studies of Pongamia pinnata Pierre using aqueous extracts of seed powder and callus. Octa. J. Biosci. 3, 7-8. 